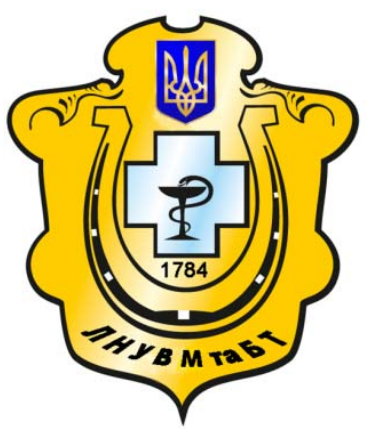

Науковий вісник Львівського національного університету ветеринарної медицини та біотехнологій імені С.3. Гжицького

Scientific Messenger of Lviv National University of Veterinary Medicine and Biotechnologies named after S.Z. Gzhytskyj

doi:10.15421/nvlvet7107

ISSN 2413-5550 print

ISSN 2518-1327 online

$\underline{\text { http://nvlvet.com.ua/ }}$

УДК 636.52 |.58.087.7:637.54 652.07

\title{
Кількісний і якісний амінокислотний склад м'яса курчат-бройлерів за збагачення раціону наномікроелементною кормовою добавкою «Мікростимулін»
}

\author{
В.М. Кириченко \\ kyrychenko111090@mail.ru
}

\author{
Харківська державна зооветеринарна академія, \\ вул. Ювілейна, 1, смт Мала Данилівка, Дергачівський р-н, Харківська обл., 62341, Украӥна,
}

\begin{abstract}
В роботі проаналізовано кількісний $і$ якісний амінокислотний склад м'яса курчат-бройлерів за збагачення рачіону наномікроелементною кормовою добавкою «Мікростимулін». Встановлено, що у м'язах птиці контрольної та дослідних груп $\epsilon$ такі незамінні амінокислоти: треонін, валін, ізолейцин, лейцин, фенілаланін, лізин, метіонін, циистін та триптофан. Дослідження якісного складу замінних амінокислот показали наявність аспарагінової кислоти, серину, гліџину, тирозин, аланіну, глутамінової кислоти, проліну, гістидину, аргініну та оксипроліну.

Встановлено, що застосування «Мікростимуліну» підвищує вміст амінокислот у м'ясі курчат-бройлерів. У м'язах курчат-бройлерів 1-ї дослідної групи, яким додавали «Мікростимулін» в дозі 1 мл/дм води, кількість незамінних та замінних амінокислот має тенденцію до збільшення в грудних, і стегнових м'язах, порівняно з контролем. Очевидно, ие можна пояснити покращенням засвоєння корму та стимулюванням синтезу амінокислот під впливом складників иієї кормової добавки. У курчат 2-ї дослідної групи, яким задавали «Мікростимулін» у дозі 10 мл/дм води, реєструється тенденція до збільшення незамінних амінокислот у грудних м'язах, проте у стегнових -простежується тенденція до їх зменшення. У курчат 3-ї дослідної групи, яким задавали «Мікростимулін» у дозі 20 мл/дм³ води, реєструється тенденція до зменшення кількості незамінних амінокислот у грудних і стегнових м'язах. Кількість замінних амінокислот у грудних м'язах курчат 2-ї дослідної групи теж дещо збільшується, а у 3 - незначно зменшується, проте у стегнових м'язах - дещо зменшується $і$ в 2-й $і$ в 3-й дослідних групах, порівняно з контролем.

Доведено, що застосування наномікроелементної кормової добавки «Мікростимулін» в дозі 1 мл/дм води покращує якість і підвищує біологічну цінність м'яса.

Ключові слова: курчата-бройлери, наномікроелементна кормова добавка «Мікростимулін», амінокислотний склад, якість м'яса, грудні м'язи, стегнові м'язи.
\end{abstract}

\section{Количественный и качественный аминокислотный состав мяса цыплят- бройлеров за обогащения рациона наномикроелементной кормовой добавкой «Микростимулин»}

\author{
В.Н. Кириченко \\ kyrychenko111090@mail.ru
}

Харьковская государственная зооветеринарная академия,

ул. Академическая, 1, пгт Малая Даниловка, Дергачёвский р-н, Харьковская обл., 62341, Украина

В работе проанализирован количественный и качественный аминокислотный состав мяса цььплят-бройлеров при обогащении рациона наномикроэлементной кормовой добавкой «Микростимулин». Установлено, что в мышиах птицы контрольной и опытных групп регистрируються такие незаменимые аминокислоты: треонин, валин, изолейцин, лейцин, фенилаланин, лизин, метионин, иистин и триптофан. Исследование качественного состава заменимых аминокислот показало

\section{Citation:}

Kirichenko, V.N. (2016). Qualitative and quantitative amino acid composition of broiler meat for enrichment their rations with nanotraceelement feed additive «Mikrostymulin». Scientific Messenger LNUVMBT named after S.Z. Gzhytskyj, 18, 3(71), 30-36. 
наличие аспарагиновой кислоты, серина, глицина, тирозин, аланина, глутаминовой кислоты, пролина, гистидина, аргинина и оксипролина.

Установлено, что применение «Микростимулина» повышает содержание аминокислот в мясе изыплят-бройлеров. В мышичах ирыплят-бройлеров 1-й опытной группы, которым добавляли «Микростимулин» в дозе 1 мл/дм водыл, количество незаменимых и заменимых аминокислот имеет тенденциию к увеличению в грудных и в бедренных мышиах, по сравнению с контролем. Очевидно, это можно объяснить улучшением усвоения корма и стимулированием синтеза аминокислот под воздействием составляющих этой кормовой добавки. У цуыплят 2-й опьтной группь, которым задавали «Микростимулин» в дозе 10 мл/дм воды, регистрируется тенденция к увеличению незаменимых аминокислот в грудных мылицах, однако в бедренных - регистрируеться тенденция к их уменьшению. У цуыплят 3-й опытной группы, которым задавали «Микростимулин» в дозе 20 мл/дм воды, регистрируется тенденция к уменьшению незаменимых аминокислот в грудных и бедренных мышичах. Количество заменимых аминокислот в грудных мышичах птицы 2-й опытной группы такље несколько увеличивается, а в 3-й-незначительно уменьшается; в бедренных мышщиах - несколько уменьшается - во 2-й и в 3-й опьтных группах, по сравнению с контролем.

Доказано, что применение наномикроелементнои кормовой добавки «Микростимулин»в дозе 1 мл/дм воды улучиает качество и повышает биологическую иенность мяса.

Ключевые слова: ичыплята-бройлеры, наномикроелементная кормовая добавка «Микростимулин», аминокислотный состав, качество мяса, грудные мышщьы, бедренные мыцицы.

\title{
Qualitative and quantitative amino acid composition of broiler meat for enrichment their rations with nanotraceelement feed additive «Mikrostymulin»
}

\author{
V.N. Kirichenko \\ kyrychenko111090@mail.ru
}

Kharkiv State Zooveterinary Academy, Akademichna Str., 1, Mala Danylivka, Kharkiv region, Dergachi district, 62341, Ukraine,

\begin{abstract}
The work analyzes qualitative and quantitative amino acid composition of broiler meat for diet enrichment nanotracelement feed additive «Mikrostymulin». It was founded that poultry muscle in control and experimental groups contain such essential amino acids, as threonine, valine, isoleucine, leucine, phenylalanine, lysine, methionine, and tryptophan tsystin. Research the quality of the essential amino-acids showed the presence of aspartic acid, serine, glycine, tyrosine, alanine, glutamic acid, proline, histidine, arginine and oxyproline.

It was established that the use of «Mikrostymulin» increases the content of amino acids in meat of broiler chickens. In muscles of broiler chickens in the 1st research group, have beenadded «Mikrostymulin» in a dose of $1 \mathrm{ml} / \mathrm{dm}^{3}$ of water, the amount of essential amino acids and replacement tends to increase at chest and hip muscles, compared with the contro group.. Obviously, this can be explained by improved assimilation of food and stimulating the synthesis of amino acids under the influence of the components of the feed additive. In chickens of the $2 \mathrm{nd}$ research group, they received «Mikrostymulin» at a dose of $10 \mathrm{ml} / \mathrm{dm}^{3}$ water, it was registered a tendency to increase essential amino acids in the pectoral muscles, but in the femoral -it was tendency to decrease. In chickens of the $3 \mathrm{rd}$ research group, they received «Mikrostymulin» at a dose of $20 \mathrm{ml} / \mathrm{dm}^{3}$ water, it was registered a tendency to reduce the amount of essential amino acids in the chest and thigh muscles. Number of essential amino-acids in chicken pectoral muscle in the 2 nd experimental group also increased slightly, and in the $3 \mathrm{rd}$ - reduced slightly, but in the femoral muscles they decreased slightly in the 2 nd and $3 \mathrm{rd}$ experimental groups compared to control group.

It is proved that the use of nanotracelement feed additive «Mikrostymulin» in a dose of $1 \mathrm{ml} / \mathrm{dm}^{3}$ of water improves the quality and increases the biological value of meat.
\end{abstract}

Key words: broiler chickens, feed additive nanotracelement «Mikrostymulin» amino acid composition, quality of meat, pectoral muscles, hip muscles.

\section{Вступ}

У птахівництві активно застосовують різноманітні кормові добавки для підвищення продуктивності птиці, покращення якості їх продукції, стимулювання імунітету тощо (Kal'nyckyj, 1985; Klicenko et al., 2001; Cowison et al., 2002; Lemesheva, 2006; Zabolotnij et al., 2007; Reutova, 2010; Berezovs'kyj and Fotyna, 2010, 2011). Зокрема, у птахівництві, все частіше збагачують раціон наночастиноками металів (Borysevych et al., 2009; Berezovs'kyj and Fotyna, 2012; Kocjumbas et al., 2014). Однією із таких кормових добавок $є$ наномікроелементна кормова добавка «Мікростимулін», яку досліджували, як препарат для підвищення імунітету курчат-бройлерів за різних хвороб (Fotina and Kovalenko, 2012; Berezovs'kyj and Fotyna, 2013; Berezjvskiy et al., 2014). Проте в сучасній науковій літе- ратурі відсутні відомості щодо оцінки впливу цієї кормової добавки на показники якості м'яса курчатбройлерів, зокрема на його кількісний і якісний амінокислотний склад.

Мета дослідження - встановити вплив наномікроелементної кормової добавки (НМКД) «Мікростимулін» на кількісний та якісний амінокислотний склад м'яса курчат-бройлерів.

Для досягнення мети роботи були поставлені наступні завдання:

встановити кількість незамінних амінокислот в грудних та стегнових м'язах курчат-бройлерів; встановити кількість замінних амінокислот в грудних та стегнових м'язах курчат-бройлерів; визначити співвідношення триптофану до оксипроліну в грудних та стегнових м'язах курчатбройлерів. 


\section{Матеріал і методи дослідження}

Для дослідження використані курчата-бройлери кросу Кобб 500 забійного віку (42-а доба). Протягом життя курчат годували сухими повнораціонними комбікормами фірми ТОВ «Фідлайф» (основний раціон) у відповідності до норм ВНДТП. Курчатамбройлерам 3 1-ї до 18-ї доби задавали стартовий, 3 19-ї до 37-ї доби - відгодівельний і з 38-ї до 42-ї доби - фінішний комбікорм.

В годівлі курчат використовували НМКД «Мікростимулін», у склад якої входять наномікроелементи: Купрум, Кобальт, Манган, Цинк, Аргентум, Германій, отримані методом Каплуненка-Косінова (ТУ У $15.7-$ 35291116-009:2011). Для дослідження було сформовано 3 дослідних і одну контрольну групи. Курчата всіх дослідних груп отримували основний раціон (ОР), а також їм випоювали «Мікростимулін» в дозі: першій дослідній групі - 1 мл/дм³, другій - 10 мл/дм³, третій групі - 20 мл/дм³ води, 5 діб поспіль 3 інтервалом 5 діб. Дослід тривав 3 5-ї до 42-ї доби життя курчат. Курчата контрольної групи отримували лише основний раціон.

Вміст незамінних і замінних амінокислот у грудних і стегнових м'язах курчат визначали на іонообмінному хроматографі аналізаторі амінокислот (ААА 339-М) за ДСТУ ISO 13903:2009. Аналіз кількісного амінокислотного складу м'яса курчат-бройлерів проводили, порівнюючи кількість замінних і незамінних амінокислот у грудних і стегнових м'язах, а також визначали співвідношення триптофану до оксипролінy.

\section{Результати та їх обговорення}

Проведеними дослідженнями встановлено, що у стегнових та грудних м'язах курчат-бройлерів контрольної і дослідних груп є як замінні, так і незамінні амінокислоти.

Iз незамінних амінокислот у м'язах курчатбройлерів виявлені такі, як треонін, валін, ізолейцин, лейцин, фенілаланін, лізин, метіонін, цистін та триптофан (табл. 1). Загальна кількість незамінних амінокислот у курчат-ройлерів 1-ї дослідної групи у грудних м'язах на 3,27\% більше від контрольної групи. Це підвищення відбувається за рахунок збільшення вмісту окремих амінокислот, таких як треоніну $(\mathrm{p} \leq 0,001)$, фенілаланіну $(\mathrm{p} \leq 0,001)$ та триптофану $(\mathrm{p} \leq 0,05)$. У птиці цієї ж групи у м'язах стегна уміст незамінних амінокислот переважає контроль на $0,63 \%$, за рахунок достовірного збільшення триптофану ( $\mathrm{p} \leq 0,01)$. У грудних м'язах курчат 2-ї дослідної групи кількість незамінних амінокислот переважає контроль на 2,85\%. Таке збільшення відбувається за рахунок треоніну ( $\mathrm{p} \leq 0,01)$, фенілаланіну ( $\mathrm{p} \leq 0,001)$ та триптофану $(\mathrm{p} \leq 0,01)$, як і в грудних м'язах птиці 1-ї дослідної групи. На відміну від збільшення вмісту незамінних амінокислот у грудних м'язах (у курчат 2-ї групи), у стегнових м'язах їх виявилося менше на 2,54\%, проти контролю, за рахунок лейцину ( $\mathrm{p} \leq 0,05)$. У грудних м'язах птиці 3-ї дослідної групи кількість незамінних амінокислот дещо менша на $0,74 \%$ за контроль, за рахунок треоніну $(\mathrm{p} \leq 0,05)$, а у стегнових - менше на $4,56 \%$ (завдяки валіну $(\mathrm{p} \leq 0,05)$, ізолейцину $(\mathrm{p} \leq 0,05)$, лейцину ( $\mathrm{p} \leq 0,01)$, гістидину $(\mathrm{p} \leq 0,01)$ та лізину $(\mathrm{p} \leq 0,05)$.

Збільшення незамінних амінокислот у грудних м'язах птиці 1-ї, 2-ї та 3-ї дослідних груп, очевидно, пов'язано із кращим засвоєнням кормів під впливом складників НМКД «Мікростимулін», зокрема Цинк, який входить до складу кормової добавки є одним із найважливіших мікроелементів, який входить до складу багатьох ферментних систем, що регулюють основні процеси обміну речовин, зокрема бере участь у синтезі білків та в обміні вуглеводів. Він забезпечує функціонування більш ніж 200 металоферментів (наприклад, карбоангідрази, карбоксипептидази А, алкогольдегідрогенази, лужної фосфатази, РНКполімерази тощо), а також для збереження правильної структури нуклеїнових кислот, білків та клітинних мембран; сприяє росту та розвитку клітин, правильному функціонуванню імунної системи.

Аргентум у поєднанні з Купрумом характеризуються бактерицидними властивостями, зокрема у шлунково-кишковому каналі птиці, подавляючи розвиток патогенної мікрофлори та покращуючи засвоєння корму.

Магній бере участь в роботі близько 300 ферментів, активізує вітамін біотин, який необхідний для енергетики организму і росту клітин.

Кобальт сконцентрований у скелетних м’язах. Він задіяний у білковому, жировому й вуглеводному обміні речовин, $є$ активатором багатьох травних ферментів, а також обов'язковим компонентом витаміну $\mathrm{B}_{12}$.

У стегнових м'язах курчат-бройлерів 1-ї дослідної групи загальна кількість незамінних амінокислот дещо збільшується відносно контролю, на відміну від їх вмісту у курчат 2-ї та 3-ї дослідних груп, у яких реєструється незначне зменшення кількості цих амінокислот. Очевидно, це пов'язано 3 фізіологічними потребами організму курчат-бройлерів та властивостями амінокислот, за рахунок, яких відбувається зменшення їх загальної кількості.

Отже, НМКД «Мікростимулін» в дозі 1 мл/ дм води покращує засвоєння корму організмом птиці, а 3 підвищенням дози кормової добавки визначені нами незамінні амінокислоти мають тенденцію до зменшення.

Порівнянням загальної кількості незамінних амінокислот у грудних та стегнових м'язах курчатбройлерів дослідних груп з контрольною, з'ясували, що найбільша їх кількість спостерігається у м'язах курчат 1-ї дослідної групи. У м’язах птиці 2-ї групи загальна кількість незамінних амінокислот дещо переважає контрольну групу лише у грудних м'язах, проте в стегнових м'язах - реєструється дещо менша їх кількість проти контролю. 
Вміст незамінних амінокислот у м'ясі курчат-бройлерів, г/100 г, (M \pm m, n=5)

\begin{tabular}{|c|c|c|c|c|c|c|c|c|}
\hline \multirow[t]{2}{*}{ Амінокис-лоти } & \multicolumn{2}{|c|}{ Контрольна група } & \multicolumn{2}{|c|}{$\begin{array}{c}1-\text { - група } \\
(1 \text { мл/дм³) }\end{array}$} & \multicolumn{2}{|c|}{$\begin{array}{c}\text { 2-a група } \\
(10 \text { мл/дм³ })\end{array}$} & \multicolumn{2}{|c|}{$\begin{array}{c}\text { 3-я група } \\
(20 \text { мл/дм³ })\end{array}$} \\
\hline & $\begin{array}{l}\text { Грудні } \\
\text { м'язи }\end{array}$ & $\begin{array}{l}\text { Стегнові } \\
\text { м'язи }\end{array}$ & $\begin{array}{l}\text { Грудні } \\
\text { м’язи }\end{array}$ & $\begin{array}{l}\text { Стегнові } \\
\text { м'язи }\end{array}$ & $\begin{array}{l}\text { Грудні } \\
\text { м’язи }\end{array}$ & $\begin{array}{l}\text { Стегнові } \\
\text { м'язи }\end{array}$ & $\begin{array}{l}\text { Грудні } \\
\text { м'язи }\end{array}$ & $\begin{array}{l}\text { Стегнові } \\
\text { м'язи }\end{array}$ \\
\hline Треонін & $\begin{array}{c}0,87 \\
\pm 0,014\end{array}$ & $\begin{array}{c}0,78 \\
\pm 0,017\end{array}$ & $\begin{array}{c}0,96 \\
\pm 0,011 \\
* * *\end{array}$ & $\begin{array}{c}0,78 \\
\pm 0,014\end{array}$ & $\begin{array}{c}0,95 \\
\pm 0,009 \\
* *\end{array}$ & $\begin{array}{c}0,73 \\
\pm 0,028\end{array}$ & $\begin{array}{c}0,93 \\
\pm 0,016 \\
*\end{array}$ & $\begin{array}{c}0,75 \\
\pm 0,015\end{array}$ \\
\hline \multicolumn{3}{|c|}{ \%, до контролю } & $+10,35$ & - & $+9,20$ & $-6,41$ & $+6,90$ & $-3,85$ \\
\hline Валін & $\begin{array}{c}1,11 \\
\pm 0,025\end{array}$ & $\begin{array}{c}0,96 \\
\pm 0,025\end{array}$ & $\begin{array}{c}1,15 \\
\pm 0,022\end{array}$ & $\begin{array}{c}0,96 \\
\pm 0,019\end{array}$ & $\begin{array}{c}1,12 \\
\pm 0,023\end{array}$ & $\begin{array}{c}0,91 \\
\pm 0,017\end{array}$ & $\begin{array}{c}1,10 \\
\pm 0,013\end{array}$ & $\begin{array}{c}0,87 \\
\pm 0,027^{*}\end{array}$ \\
\hline \multicolumn{3}{|c|}{ \%, до контролю } & $+3,60$ & - & $+0,90$ & $-5,21$ & $-0,90$ & $-9,38$ \\
\hline Ізолейцин & $\begin{array}{c}1,05 \\
\pm 0,019\end{array}$ & $\begin{array}{c}0,90 \\
\pm 0,026 \\
\end{array}$ & $\begin{array}{c}1,08 \\
\pm 0,016\end{array}$ & $\begin{array}{c}0,92 \\
\pm 0,023\end{array}$ & $\begin{array}{c}1,05 \\
\pm 0,014\end{array}$ & $\begin{array}{c}0,88 \\
\pm 0,024\end{array}$ & $\begin{array}{c}1,02 \\
\pm 0,009\end{array}$ & $\begin{array}{c}0,82 \\
\pm 0,023^{*}\end{array}$ \\
\hline \multicolumn{3}{|c|}{$\%$, до контролю } & $+2,78$ & $+2,17$ & - & $-2,22$ & $-2,86$ & $-8,89$ \\
\hline Лейцин & $\begin{array}{c}1,68 \\
\pm 0,018\end{array}$ & $\begin{array}{c}1,47 \\
\pm 0,021\end{array}$ & $\begin{array}{c}1,75 \\
\pm 0,027\end{array}$ & $\begin{array}{c}1,47 \\
\pm 0,027\end{array}$ & $\begin{array}{c}1,72 \\
\pm 0,011\end{array}$ & $\begin{array}{c}1,40 \\
\pm 0,015^{*}\end{array}$ & $\begin{array}{c}1,66 \\
\pm 0,035\end{array}$ & $\begin{array}{c}1,36 \\
\pm 0,014 * *\end{array}$ \\
\hline \multicolumn{3}{|c|}{ \%, до контролю } & $+4,00$ & - & $+2,38$ & $-4,76$ & $-1,19$ & $-7,48$ \\
\hline Фенілала-нін & $\begin{array}{c}0,84 \\
\pm 0,016\end{array}$ & $\begin{array}{c}0,72 \\
\pm 0,019\end{array}$ & $\begin{array}{c}0,96 \\
\pm 0,011 \\
* * *\end{array}$ & $\begin{array}{c}0,73 \\
\pm 0,019\end{array}$ & $\begin{array}{c}0,96 \\
\pm 0,013 \\
* * *\end{array}$ & $\begin{array}{c}0,72 \\
\pm 0,018\end{array}$ & $\begin{array}{c}0,84 \\
\pm 0,014\end{array}$ & $\begin{array}{c}0,71 \\
\pm 0,016\end{array}$ \\
\hline \multicolumn{3}{|c|}{ \%, до контролю } & $+12,50$ & $+1,37$ & $+14,29$ & - & - & $-1,39$ \\
\hline Лізин & $\begin{array}{c}1,89 \\
\pm 0,015\end{array}$ & $\begin{array}{c}1,62 \\
\pm 0,021\end{array}$ & $\begin{array}{c}1,94 \\
\pm 0,024\end{array}$ & $\begin{array}{c}1,63 \\
\pm 0,015\end{array}$ & $\begin{array}{c}1,90 \\
\pm 0,020\end{array}$ & $\begin{array}{c}1,61 \\
\pm 0,016\end{array}$ & $\begin{array}{c}1,89 \\
\pm 0,014\end{array}$ & $\begin{array}{c}1,55 \\
\pm 0,020^{*}\end{array}$ \\
\hline \multicolumn{3}{|c|}{$\%$, до контролю } & $+2,58$ & $+0,61$ & $+0,53$ & $-0,62$ & - & $-4,32$ \\
\hline Метіонін & $\begin{array}{c}0,63 \\
\pm 0,025 \\
\end{array}$ & $\begin{array}{c}0,51 \\
\pm 0,013 \\
\end{array}$ & $\begin{array}{c}0,64 \\
\pm 0,011 \\
\end{array}$ & $\begin{array}{c}0,52 \\
\pm 0,019 \\
\end{array}$ & $\begin{array}{c}0,64 \\
\pm 0,024 \\
\end{array}$ & $\begin{array}{c}0,51 \\
\pm 0,021 \\
\end{array}$ & $\begin{array}{c}0,64 \\
\pm 0,012 \\
\end{array}$ & $\begin{array}{c}0,52 \\
\pm 0,019 \\
\end{array}$ \\
\hline \multicolumn{3}{|c|}{ \%, до контролю } & $+1,56$ & $+1,92$ & $+1,59$ & - & $+1,59$ & $+1,92$ \\
\hline Цистін & $\begin{array}{c}0,24 \\
\pm 0,014\end{array}$ & $\begin{array}{c}0,20 \\
\pm 0,015 \\
\end{array}$ & $\begin{array}{c}0,26 \\
\pm 0,014 \\
\end{array}$ & $\begin{array}{c}0,22 \\
\pm 0,016\end{array}$ & $\begin{array}{c}0,25 \\
\pm 0,014\end{array}$ & $\begin{array}{c}0,20 \\
\pm 0,015\end{array}$ & $\begin{array}{c}0,25 \\
\pm 0,014\end{array}$ & $\begin{array}{c}0,21 \\
\pm 0,013\end{array}$ \\
\hline \multicolumn{3}{|c|}{$\%$, до контролю } & $+7,69$ & $+9,09$ & $+4,17$ & - & $+4,17$ & $+5,00$ \\
\hline Триптофан & $\begin{array}{c}0,30 \\
\pm 0,007\end{array}$ & $\begin{array}{c}0,23 \\
\pm 0,003\end{array}$ & $\begin{array}{c}0,33 \\
\pm 0,007 \\
*\end{array}$ & $\begin{array}{c}0,25 \\
\pm 0,003 \\
* *\end{array}$ & $\begin{array}{c}0,33 \\
\pm 0,004 \\
* *\end{array}$ & $\begin{array}{c}0,24 \\
\pm 0,005\end{array}$ & $\begin{array}{c}0,33 \\
\pm 0,006 \\
*\end{array}$ & $\begin{array}{c}0,25 \\
\pm 0,003 \\
* *\end{array}$ \\
\hline \multicolumn{3}{|c|}{ \%, до контролю } & $+10,00$ & $+8,70$ & $+10,00$ & $+4,35$ & $+10,00$ & $+8,70$ \\
\hline Всього & $\begin{array}{c}9,48 \\
\pm 0,16 \\
\end{array}$ & $\begin{array}{c}7,89 \\
\pm 0,171 \\
\end{array}$ & $\begin{array}{c}9,79 \\
\pm 0,145 \\
\end{array}$ & $\begin{array}{c}7,94 \\
\pm 0,152 \\
\end{array}$ & $\begin{array}{c}9,75 \\
\pm 0,144 \\
\end{array}$ & $\begin{array}{c}7,69 \\
\pm 0,16 \\
\end{array}$ & $\begin{array}{c}9,41 \\
\pm 0,138 \\
\end{array}$ & $\begin{array}{c}7,53 \\
\pm 0,147 \\
\end{array}$ \\
\hline \multicolumn{3}{|c|}{\begin{tabular}{c|c} 
$\pm 0,16$ \\
$\%$, до контролю
\end{tabular}} & $+3,27$ & $+0,63$ & $+2,85$ & $-2,54$ & $-0,74$ & $-4,56$ \\
\hline
\end{tabular}

Примітка: *p $\leq 0,05,{ }^{* *} \mathrm{p} \leq 0,01,{ }^{* * *} \mathrm{p} \leq 0,001-$ порівняно з контролем.

У грудних та стегнових м'язах курчат 3-ї групи спостерігається тенденція до зменшення загальної кількісті незамінних амінокислот, порівняно 3 контролем.

Із замінних амінокислот у грудних та стегнових м'язах курчат-бройлерів виявлені такі: аспарагінова кислота, серин, тирозин, гліцин, аланін, глутамінова кислота, пролін, гістидин, аргінін та оксипролін (табл. 2). У грудних м'язах курчат 1-ї дослідної групи реєструється на 3,95\% більше загальної кількості замінних амінокислот, ніж у контролі. Це відбувається за рахунок збільшення кількості окремих амінокислот, зокрема, гліцину ( $\mathrm{p} \leq 0,05)$, глютамінової кислоти $(\mathrm{p} \leq 0,001)$, проліну $(\mathrm{p} \leq 0,001)$ та тирозину $(\mathrm{p} \leq 0,001)$. У стегнових м'язах - на 2,33\% більше загальної кількості замінних амінокислот від контролю, завдяки збільшенню кількості аспарагінової кислоти $(\mathrm{p} \leq 0,001)$. Загальна кількість замінних амінокислот у грудних м'язах курчат 2-ї групи на 0,82\% більше проти контролю, оскільки збільшився вміст глютамінової кислоти ( $\mathrm{p} \leq 0,001)$ та тирозину ( $\leq 0,001)$, а у стегнових м'язах - на 7,58\% $(\mathrm{p} \leq 0,05)$ менше за контроль, за рахунок серину $(\mathrm{p} \leq 0,001)$, гліцину $(\mathrm{p} \leq 0,001)$, аланіну ( $\mathrm{p} \leq 0,05)$, проліну ( $\mathrm{p} \leq 0,001)$, аргініну $(\mathrm{p} \leq 0,05)$. У курчат-бройлерів 3-ї дослідної групи кількість замінних амінокислот у грудних та стегнових м'язах дещо менші від контролю на 0,79\% та 8,61\% (p $\leq 0,01)$ відповідно. Це відбувається завдяки збільшенню гліцину ( $\mathrm{p} \leq 0,01)$, аланіну $(\mathrm{p} \leq 0,05)$, гістидину ( $\mathrm{p} \leq 0,01)$, аргініну $(\mathrm{p} \leq 0,01)$ та оксипроліну $(\mathrm{p} \leq 0,05)$ у грудних та аспарагінової кислоти $(\mathrm{p} \leq 0,001)$ гліцину $(\mathrm{p} \leq 0,001)$, аланіну $(\mathrm{p} \leq 0,05)$, глютамінової кислоти $(\mathrm{p} \leq 0,01)$ і тирозину $(\mathrm{p} \leq 0,01)$ у стегнових м'язах.

Замінні амінокислоти за збагачення раціону НМКД «Мікростимулін» у стегнових та грудних м'язах мають тенденцію до збільшення лише за дози 1 мл/дм ${ }^{3}$ води (1-а дослідна група). За дози 10 мл/дм води (2-а дослідна група), тенденція до збільшення кількості замінних амінокислот залишається у грудних м'язах, а у стегнових - навпаки простежується достовірне $(\mathrm{p} \leq 0,05)$ зменшення їх кількості. У грудних м'язах птиці 3-ї дослідної групи якій застосовували НМКД «Мікростимулін» у дозі 20 мл/дм³ води спостерігається тенденція до зменшення загальної кількості, порівнюючи 3 контролем, а у стегнових 
м'язах птиці загальна кількість замінних амінокислот достовірно $(\mathrm{p} \leq 0,01)$ зменшується проти контрольної групи. Очевидно, ці зміни пов'язані із здатністю скла- дників «Мікростимуліну», стимулювати синтез замінних амінокислот, але за доз 10 і 20 мл/дм³ води вони, навпаки, пригнічують їх синтез.

Вміст замінних амінокислот у м'ясі курчат-бройлерів, г/100 г, (M \pm m, n=5)

\begin{tabular}{|c|c|c|c|c|c|c|c|c|}
\hline \multirow[t]{2}{*}{ Амінокис-лоти } & \multicolumn{2}{|c|}{ Контрольна група } & \multicolumn{2}{|c|}{$\begin{array}{r}1-a \text { група } \\
\left(1 \mathrm{мл} / \text { дм }^{3}\right) \\
\end{array}$} & \multicolumn{2}{|c|}{$\begin{array}{c}2-a \text { група } \\
\left(10 \mathrm{мл} / \text { дм }^{3}\right) \\
\end{array}$} & \multicolumn{2}{|c|}{$\begin{array}{c}\text { 3-я група } \\
(20 \text { мл/дм³ }) \\
\end{array}$} \\
\hline & $\begin{array}{c}\text { Грудні } \\
\text { м'язи }\end{array}$ & $\begin{array}{c}\text { Стегнові } \\
\text { м'язи }\end{array}$ & $\begin{array}{c}\text { Грудні } \\
\text { м'язи }\end{array}$ & $\begin{array}{c}\text { Стегнові } \\
\text { м'язи }\end{array}$ & $\begin{array}{l}\text { Грудні } \\
\text { м'язи }\end{array}$ & $\begin{array}{c}\text { Стегнові } \\
\text { м'язи }\end{array}$ & $\begin{array}{c}\text { Грудні } \\
\text { м'язи }\end{array}$ & $\begin{array}{c}\text { Стегнові } \\
\text { м'язи }\end{array}$ \\
\hline $\begin{array}{c}\text { Аспарагі-нова } \\
\text { кислота }\end{array}$ & $\begin{array}{c}2,00 \\
\pm 0,042\end{array}$ & $\begin{array}{c}1,73 \\
\pm 0,012\end{array}$ & $\begin{array}{l}1,96 \\
\pm 0,050\end{array}$ & $\begin{array}{c}1,96 \\
\pm 0,009 \\
* * *\end{array}$ & $\begin{array}{l}1,97 \\
\pm 0,017\end{array}$ & $\begin{array}{c}1,63 \\
\pm 0,009 \\
* * *\end{array}$ & $\begin{array}{l}1,93 \\
\pm 0,019\end{array}$ & $\begin{array}{c}1,61 \\
\pm 0,012 \\
* * *\end{array}$ \\
\hline \multicolumn{3}{|c|}{ \% до контролю } & $-2,00$ & $+13,30$ & $-1,50$ & $-5,78$ & $-3,50$ & $-6,94$ \\
\hline Серин & $\begin{array}{c}0,80 \\
\pm 0,016\end{array}$ & $\begin{array}{c}0,64 \\
\pm 0,007\end{array}$ & $\begin{array}{c}0,69 \\
\pm 0,014 \\
* * *\end{array}$ & $\begin{array}{c}0,64 \\
\pm 0,011\end{array}$ & $\begin{array}{c}0,75 \\
\pm 0,009 \\
*\end{array}$ & $\begin{array}{c}0,58 \\
\pm 0,009 \\
* * *\end{array}$ & $\begin{array}{c}0,76 \\
\pm 0,012\end{array}$ & $\begin{array}{c}0,66 \\
\pm 0,017\end{array}$ \\
\hline \multicolumn{3}{|c|}{ \% до контролю } & $-13,75$ & - & $-6,25$ & $-9,38$ & $-5,00$ & $+3,13$ \\
\hline Гліцин & $\begin{array}{c}0,99 \\
\pm 0,019\end{array}$ & $\begin{array}{c}0,92 \\
\pm 0,012\end{array}$ & $\begin{array}{c}1,05 \\
\pm 0,016 \\
\quad *\end{array}$ & $\begin{array}{c}0,92 \\
\pm 0,012\end{array}$ & $\begin{array}{c}0,89 \\
\pm 0,013 \\
\quad * *\end{array}$ & $\begin{array}{c}0,77 \\
\pm 0,020 \\
* * *\end{array}$ & $\begin{array}{c}0,91 \\
\pm 0,013 \\
* *\end{array}$ & $\begin{array}{c}0,55 \\
\pm 0,016 \\
* * *\end{array}$ \\
\hline \multicolumn{3}{|c|}{ \% до контролю } & $+6,06$ & - & $-10,10$ & $-16,30$ & $-8,08$ & $-40,22$ \\
\hline Аланін & $\begin{array}{c}1,24 \\
\pm 0,014\end{array}$ & $\begin{array}{l}1,11 \\
\pm 0,027\end{array}$ & $\begin{array}{l}1,26 \\
\pm 0,016\end{array}$ & $\begin{array}{c}1,10 \\
\pm 0,040\end{array}$ & $\begin{array}{l}1,22 \\
\pm 0,016\end{array}$ & $\begin{array}{c}1,01 \\
\pm 0,017 *\end{array}$ & $\begin{array}{c}1,19 \\
\pm 0,008^{*}\end{array}$ & $\begin{array}{c}1,01 \\
\pm 0,013 *\end{array}$ \\
\hline \multicolumn{3}{|c|}{ \%, до контролю } & $+1,61$ & $-0,90$ & $-1,61$ & $-9,01$ & $-4,03$ & $-9,01$ \\
\hline $\begin{array}{c}\text { Глутаміно-ва } \\
\text { кислота }\end{array}$ & $\begin{array}{c}3,00 \\
\pm 0,032\end{array}$ & $\begin{array}{c}2,91 \\
\pm 0,041\end{array}$ & $\begin{array}{c}3,30 \\
\pm 0,022 \\
* * *\end{array}$ & $\begin{array}{c}2,90 \\
\pm 0,037\end{array}$ & $\begin{array}{c}3,20 \\
\pm 0,017 \\
* * *\end{array}$ & $\begin{array}{c}2,81 \\
\pm 0,031\end{array}$ & $\begin{array}{c}3,17 \\
\pm 0,012 \\
* *\end{array}$ & $\begin{array}{c}2,67 \\
\pm 0,030 \\
* *\end{array}$ \\
\hline \multicolumn{3}{|c|}{ \%, до контролю } & $+10,00$ & $-0,34$ & $+6,67$ & $-3,44$ & $+5,67$ & $-8,25$ \\
\hline Пролін & $\begin{array}{c}0,84 \\
\pm 0,009\end{array}$ & $\begin{array}{c}0,81 \\
\pm 0,020\end{array}$ & $\begin{array}{c}0,91 \\
\pm 0,009 \\
* * *\end{array}$ & $\begin{array}{c}0,82 \\
\pm 0,019\end{array}$ & $\begin{array}{c}0,80 \\
\pm 0,012 \\
*\end{array}$ & $\begin{array}{c}0,66 \\
\pm 0,021 \\
* * *\end{array}$ & $\begin{array}{c}0,85 \\
\pm 0,012\end{array}$ & $\begin{array}{c}0,89 \\
\pm 0,020 \\
*\end{array}$ \\
\hline \multicolumn{3}{|c|}{ \%, до контролю } & $+8,33$ & $+1,24$ & $-4,76$ & $-18,52$ & $+1,19$ & $+9,88$ \\
\hline Тирозин & $\begin{array}{c}0,84 \\
\pm 0,017\end{array}$ & $\begin{array}{c}0,67 \\
\pm 0,012\end{array}$ & $\begin{array}{c}1,01 \\
\pm 0,013 \\
* * *\end{array}$ & $\begin{array}{c}0,68 \\
\pm 0,019\end{array}$ & $\begin{array}{c}0,99 \\
\pm 0,012 \\
* * *\end{array}$ & $\begin{array}{c}0,66 \\
\pm 0,012\end{array}$ & $\begin{array}{c}0,88 \\
\pm 0,026\end{array}$ & $\begin{array}{c}0,58 \\
\pm 0,017 \\
* *\end{array}$ \\
\hline \multicolumn{3}{|c|}{ \%, до контролю } & $+16,83$ & $+1,47$ & $+17,86$ & $-1,49$ & $+4,76$ & $-13,43$ \\
\hline Гістидин & $\begin{array}{c}1,11 \\
\pm 0,021\end{array}$ & $\begin{array}{c}0,70 \\
\pm 0,026\end{array}$ & $\begin{array}{c}0,98 \\
\pm 0,016 \\
* *\end{array}$ & $\begin{array}{c}0,68 \\
\pm 0,013\end{array}$ & $\begin{array}{c}1,08 \\
\pm 0,026\end{array}$ & $\begin{array}{c}0,69 \\
\pm 0,016\end{array}$ & $\begin{array}{c}1,00 \\
\pm 0,019 \\
* *\end{array}$ & $\begin{array}{c}0,70 \\
\pm 0,010\end{array}$ \\
\hline \multicolumn{3}{|c|}{$\%$ до контролю } & $-11,71$ & $-2,86$ & $-2,70$ & $-1,43$ & $-9,91$ & - \\
\hline Аргінін & $\begin{aligned} & 1,45 \\
& \pm 0,014 \\
&\end{aligned}$ & $\begin{array}{c}1,23 \\
\pm 0,027 \\
\end{array}$ & $\begin{array}{c}1,41 \\
\pm 0,014 \\
\end{array}$ & $\begin{array}{c}1,22 \\
\pm 0,026 \\
\end{array}$ & $\begin{array}{l}1,42 \\
\pm 0,014 \\
\end{array}$ & $\begin{array}{c}1,12 \\
\pm 0,028^{*} \\
\end{array}$ & $\begin{array}{c}1,37 \\
\pm 0,014 * * \\
\end{array}$ & $\begin{array}{l}1,16 \\
\pm 0,015 \\
\end{array}$ \\
\hline \multicolumn{3}{|c|}{ \%, до контролю } & $-2,76$ & $-0,81$ & $-2,07$ & $-8,94$ & $-5,52$ & $-5,69$ \\
\hline Оксипролін & $\begin{array}{c}0,06 \\
\pm 0,002\end{array}$ & $\begin{array}{c}0,04 \\
\pm 0,003\end{array}$ & $\begin{array}{c}0,06 \\
\pm 0,002\end{array}$ & $\begin{array}{c}0,04 \\
\pm 0,003\end{array}$ & $\begin{array}{c}0,06 \\
\pm 0,003\end{array}$ & $\begin{array}{c}0,04 \\
\pm 0,002\end{array}$ & $\begin{array}{c}0,06 \\
\pm 0,002\end{array}$ & $\begin{array}{c}0,04 \\
\pm 0,003\end{array}$ \\
\hline \multicolumn{3}{|c|}{ \%, до контролю } & - & - & - & - & - & - \\
\hline Всього & $\begin{array}{r}11,46 \\
\pm 0,179 \\
\end{array}$ & $\begin{array}{c}10,26 \\
\pm 0,176\end{array}$ & $\begin{array}{c}11,91 \\
\pm 0,17\end{array}$ & $\begin{array}{c}10,50 \\
\pm 0,192\end{array}$ & $\begin{array}{c}11,55 \\
\pm 0,127 \\
\end{array}$ & $\begin{aligned} & 9,48 \\
\pm & 0,164 *\end{aligned}$ & $\begin{array}{c}11,37 \\
\pm 0,132\end{array}$ & $\begin{array}{c}9,38 \\
\pm 0,156^{* *}\end{array}$ \\
\hline \multicolumn{3}{|c|}{ \%, до контролю } & $+3,95$ & $+2,33$ & $+0,82$ & $-7,58$ & $-0,79$ & $-8,61$ \\
\hline
\end{tabular}

Примітка: ${ }^{*} \mathrm{p} \leq 0,05,{ }^{* *} \mathrm{p} \leq 0,01, * * * \mathrm{p} \leq 0,001-$ порівняно 3 контролем.

Застосування курчатам-бройлерам НМКД «Мікростимулін» у дозі 1 мл/дм³ води (1-а дослідна група) дещо підвищує кількість замінних амінокислот як у стегнових, так і у грудних м'язах птиці. Проте підвищення дози «Мікростимуліну» до 10 мл/дм³ води (2-a дослідна група) характеризується тенденцією до незначного збільшення кількості замінних амінокислот лише у грудних м'язах курчат. У 3-й дослідній групі, курчата-бройлери якої отримували кормову добавку у

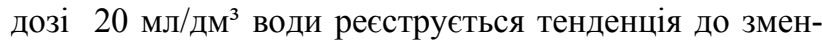
шення загальної кількості замінних амінокислот у грудних та достовірне $(\mathrm{p} \leq 0,01)$ зменшення у стегнових м'язах, порівняно 3 контролем. Очевидно, ці зміни пов'язані із здатністю складників «Мікростимуліну» та дози цієї кормової добавки стимулювати синтез замінних амінокислот.

Найбільша кількість замінних амінокислот у грудних і стегнових м'язах курчат-бройлерів реєструється у курчат-бройлерів 1-ї дослідної групи, а у 2-ій та 3ій -іх кількість має тенденцію до зменшення проти контролю.

Співвідношення незамінних та замінних амінокислот у грудних та стегнових м'язах курчат-бройлерів

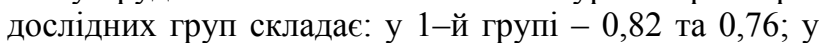
2-й групі - 0,84 та 0,81 відповідно; у $3-$ й групі - 0,83 та 0,80 , а у контрольній групі - 0,83 та 0,77 відповід- 
но. Таким чином, у м'язах курчат-бройлерів 2-ї дослідної групи співвідношення амінокислот має тенденцію до збільшення проти контролю, у м'язах птиці 1-ї дослідної групи - має тенденцію до зменшення, а у досліджених зразках м'язів птиці 3-ї дослідної групи - має тенденцію до збільшення у стегнових м'язах, проте у грудних - відповідає контролю.

Для встановлення біологічної цінності грудних та стегнових м'язів курчат-бройлерів контрольної і всіх дослідних груп ми розрахували співвідношення триптофану до оксипроліну (рис. 1).

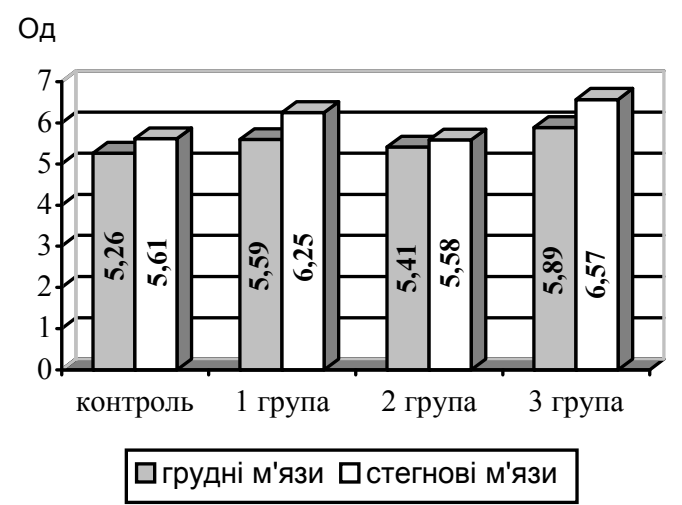

\section{Рис. 1. Співвідношення триптофану і оксипро- ліну в грудних та стегнових м'язах курчат- бройлерів}

Встановлено, що у м'язах курчат-бройлерів 1-ї і 3-ї дослідних груп реєструється тенденція до збільшення співвідношення триптофану та оксипроліну, порівняно 3 контролем, проте лише у м'язах птиці 2-ї дослідної групи спостерігається його незначне зменшення у стегнових м'язах.

\section{Висновки}

1. Амінокислотний склад м'яса курчат-бройлерів залежить від заданої дози наномікроелементної кормової добавки «Мікростимулін».

2. Збагачення раціону курчат-бройлерів наномікроелементною кормовою добавкою «Мікростимулін» у дозі 1 мл/дм³ води призводить до покращення біологічної цінності м'яса за рахунок збільшення замінних та незамінних амінокислот у грудних м'язах на 3,95 \% та 3,27 \% відповідно, а у стегнових - на 2,33\% та 0,63 \% відповідно. Очевидно, це пояснюється покращенням засвоєння корму та стимулюванням синтезу амінокислот під впливом складників цієї кормової добавки.

3. У грудних та стегнових м'язах курчатбройлерів 2-ї (10 мл/дм³) та 3-ї (20 мл/дм³) дослідних груп реєструється дещо менша кількість амінокислот, порівняно 3 1-ю дослідною групою.

4. У птиці 1-ї і 3-ї дослідних груп реєструється тенденція до збільшення співвідношення триптофану та оксипроліну, порівняно 3 контролем. Лише у курчат 2-ї дослідної групи спостерігається його незначне зменшення у стегнових м'язах.
Перспективи подальших досліджень. В системі ветеринарно-санітарної експертизи продуктів забою курчат-бройлерів, раціон яких збагачували НМКД «Мікростимулін», ці дослідження будуть доповнені характеристикою жирно-кислотного, вітамінного, мінерального складу м'яса.

\section{Бібліографічні посилання}

Zabolotnij, M.V., Kurycina, V.M., Mal'ceva, P.M. (2007). Polnocennost' belka mjasa brojlerov pry prymenenyy $\mathrm{v}$ racyone ekstrakta sapropelja [The usefulness of the protein of broiler meat in the diet in the application of sapropel extract]. Ptycevodstvo [Poultry farming], 32-33 (in Russian).

Kal'nyckyj, B.D. (1985). Myneral'nie veshhestva v kormlenyy zhyvotnih [Minerals in animal nutrition]. Lviv.: Agropromyzdat (in Russian).

Klicenko, G.T., Kulyk, M.F., Kosenko, M.V., Lisovenko, V.T. (2001). Mineral'ne zhyvlennja tvaryn [Mineral nutrition of animals]. Kyi'v: Svit (in Ukrainian).

Lemesheva, M.M. (2006). Amynokyslotnoe pytanye ptycy [Amino acid nutrition of poultry]. Zhyvotnovodstvo Rossyy [Livestock Russia], 25-27 (in Russian).

Reutova, E.A. (2010). Amynokyslotnij sostav belkov y kachestvo mjasa cipljat-brojlerov pry yspol'zovanyy ymunomoduljatorov [The amino acid composition of proteins and quality of broiler meat using imunomodulyatorov]. Uchenie zapysky KGAVM [Scientific notes KGAVM]. 1(204), 236-239 (in Russian).

Cowison, A.J., Silva, S., Priyankarage, P., Guranatne, N. (2002). The effect of dietary enzymes on the endogenous Rosses from nutrient utilization and nitrogen exeretion in broiler chickens. Brif. Poultry Sc. 43(5), 48-50.

Berezovs'kyj, A.V., Fotyna, A.A. (2010). Sovremennie hymyoterapevtycheskye sredstva $\mathrm{v}$ tehnologyy ptycevodstva [Current chemotherapeutic agents in poultry technology]. Kyi'v: DIA (in Russian).

Berezovs'kyj, A.V., Fotina, G.A. (2011). Obgruntuvannja ta osoblyvosti vykorystannja kompleksnyh antybakterial'nyh preparativ $\mathrm{u}$ tehnologijah promyslovogo ptahivnyctva [Rationale and especially the use of antibiotics in complex industrial technologies poultry]. Metodychni rekomendacii' [Guidelines] (in Ukrainian).

Berezovs'kyj, A.V., Fotina, G.A., Kovalenko, A.V. (2012) Nanoakvahelaty mikroelementiv - jak al'ternatyva antybiotykam u systemi profilaktyky bakterioziv ptyci [Nanoakvahelaty trace elements - as an alternative to antibiotics in poultry bakteriosis prevention system]. Ptahivnyctvo : mizhvid. temat. nauk. zb. 68, 22-28 (in Ukrainian).

Kocjumbas, I., Velychko, V., Kaplunenko, V., Avdos'jeva, I. (2014) Zastosuvannja nanomikroelementnoi' kormovoi' sumishi u ptahivnyctvi [The use of nano microelements in poultry feed mixtures]. Metodychni rekomendacii' [Guidelines]. Kyi'v, 15 (in Ukrainian).

Borysevych, V.B., Borysevych, B.V., Kaplunenko, V.G., Kosinov, M.V. (2009) Vplyv nanochastok $\mathrm{Cu}, \mathrm{Zn}$, 
$\mathrm{Mg}$, Co na produktyvnist' brojleriv [The impact of nanoparticle $\mathrm{Cu}, \mathrm{Zn}, \mathrm{Mg}, \mathrm{Cu}$ performance in broilers]. Efektyvne ptahivnyctvo [Effective poultry]. 1(49), 28-31 (in Ukrainian).

Fotyna, A.A., Berezovskyj, A.V. (2013) Opredelenye effektyvnosty mykrostymulyna pry eksperymental'nom ynfekcyonnom synovyte cipljat [Determination of the effectiveness mykrostymulyna with experimental infectious Son tsuplyat]. Urgent problems of conducting agricultural manufacture inarid to azone the centre the Asian region: mat. of thein tern. Scient.-prac. conf. Novosibirsk, 228-232 (in Russian).

Berezjvskiy, A.V., Fotina, H.A., Kovalenko, A.V. (2014). Determination of protective mikrostimulin capacity in poueltry. Trace elements in medicine. Moskov, 15(2), 18-21 (in Russian).

Berezovs'kyj, A.V., Fotina, G.A., Kovalenko, A.V. (2012). Vyznachennja zahysnoi' spromozhnosti preparatu «Mikrostymulin» pry eksperymental'nomu infekcijnomu synoviti kurchat [Determining the defensive ability of the drug «Mikrostymulin» infectious synovitis in experimental chickens]. «Aktual'ni problemy veterynarnoi' medycyny $\mathrm{v}$ Ukrai'ni»: Vseukr. nauk.- prak. konf. 19 veresnja 2012 r.: tezy dopov. Poltava, 3-4 (in Ukrainian).

Fotina, G.A., Kovalenko, A.V. (2012) Vyznachennja likuval'no-profilaktychnoi' efektyvnosti novogo preparatu «Mikrostymulin» za eksperymental'nogo esheryhiozu kurchat [Definition of therapeutic and preventive efficacy of a new drug «Mikrostymulin» in experimental esheryhioz of chickens]. Visnyk Zhytomyrs'kogo nacional'nogo agroekologichnogo universytetu. Ser. «Vet. Medycyna». 2(31), 151-156 (in Ukrainian).

Dobavka mikroelementna kormova «Mikrostymulin». Tehnichni umovy. TU U 15.7-35291116-009:2011 (in Ukrainian).

DSTU ISO 13903:2009. Metod vyznachennja vmistu aminokyslot. - vved. 2011-01-01. - K. : Derzhspozhyvstandart Ukrai'ny, 2009, P. 22 (in Ukrainian).

DSTU ISO 13904:2008. Metod vyznachennja vmistu tryptofanu. - vved. 2009-01-01. - K. : Derzhspozhyvstandart Ukrai'ny, 2009, P. 19 (in Ukrainian).

Стаття надійшла до редакиії 22.08.2016 